\title{
Ougenioxylon chinjiensis sp. nov., a New Fossil Species of the Family Leguminosae from Chinji Formation Salt Range, Punjab Pakistan
}

\author{
Noor-Ul-Ain Soomro, Basir Ahmed Arain, Muhammad Tahir Mehmood Rajput \\ Institute of Plant Sciences, University of Sindh, Jamshoro, Pakistan \\ Email: noorulainsoomro1@gmail.com
}

Received 24 October 2014; revised 23 November 2014; accepted 1 December 2014

Copyright $@ 2014$ by authors and Scientific Research Publishing Inc.

This work is licensed under the Creative Commons Attribution International License (CC BY).

http://creativecommons.org/licenses/by/4.0/

\section{c) (i) Open Access}

\begin{abstract}
This work is comprised of anatomical study of fossil wood collected from Chinji formation $\left(72^{\circ} 22^{\prime} \mathrm{E}, 32^{\circ} 41^{\prime} \mathrm{N}\right)$ of Miocene age exposed at Chinji National Reservoir. The material consists of a single piece of petrified wood dark brown in colour. The three dimensional sections were prepared by ground thin section technique. Microscopic examination of the characters was compared with modern and fossil wood and found comparable with the family Leguminosae. The closest resemblance of our fossil wood is with the wood of Ougenia. This fossil wood shows close resemblance in respect of vessels, fibers, parenchyma and xylem rays character. Therefore it is considered as new species and it is named Ougenioxylon chienjiensis sp. nov. The specific epithet refers to Chinji formation to which fossil wood belongs.
\end{abstract}

Keywords

Ougenia chinjiensis, Fossil Wood, Salt Range, Punjab Pakistan

\section{Introduction}

The presence of fossilized plant remaining in the Tertiary deposits of Pakistan has been known since 1879, when Balanford [1] reported them while working on the geology of Sindh region. However no effort was made to investigate and identify these plant fossils from this region. Prof. K. M. Khan established Paleobotany research lab at Institute of Plant Sciences (formerly Department of Botany) and along with his co-workers reported a number of petrified woods from different fossiliferous localities of Sindh province (Khan \& Rahmatullah, 1968 [2]; 
Khan et al., 1971 [3]; Khan \& Rahmatullah, 1972 [4]; Khan \& Rajput, 1976 [5]; Rehmatullah et al., 1984 [6]; Rajput \& Khan, 1982 [7]; Rajput \& Khan, 1984 [8]; Saeed et al., 1984 [9]; Rajput et al., 1985 [10]; Ahmed et al., 1989 [11]; Ahmed et al., 1991 [12] [13]; Ahmed et al., 1993 [14]; Bhutto et al., 1993 [15]; Ahmed et al., 2007 [16] [17]; Shar et al., 2007 [18]). No attempt was made to explore the other provinces of Pakistan.

The present work deals with the first systematic study of a petrified wood from Punjab province, Pakistan. The petrified wood sample was collected from the fossiliferous locality of Chinji National Reservoir district Khushab, which is $50 \mathrm{~km}$ away from Khushab City and $175 \mathrm{~km}$ in northwest of Faisalabad in the heart of Salt range. Fossil woods are buried on the slopes of sedimentary rocks. Some of these fossils are in complete log of 4 - $6 \mathrm{~m}$ long. The present work deals with the anatomical description and the affinities of a fossil wood.

\section{Material and Methods}

The specimen No. TR. 20, Plate 1(a). The material (TR. 20 silicified wood was collected by the first author from Chinji National Reserve, district Khushab, Punjab Pakistan. The wood was a small piece of mature secondary xylem fossil about $9 \mathrm{~cm}$ in length and $4 \mathrm{~cm}$ in diameter. The colour of fossilized wood was brown the anatomical sections, of required direction were prepared by the conventional Rock cutting and grinding thin sections technique [19]. Most of the preliminary investigations were made with the Lietz Ortholux II light microscope and Lietz Steriozoome microscope. Photographs were taken with Ortholux II Microscope at the Paleobotany lab, Institute of Plant Science, University of Sindh, Jamshoro, Pakistan.

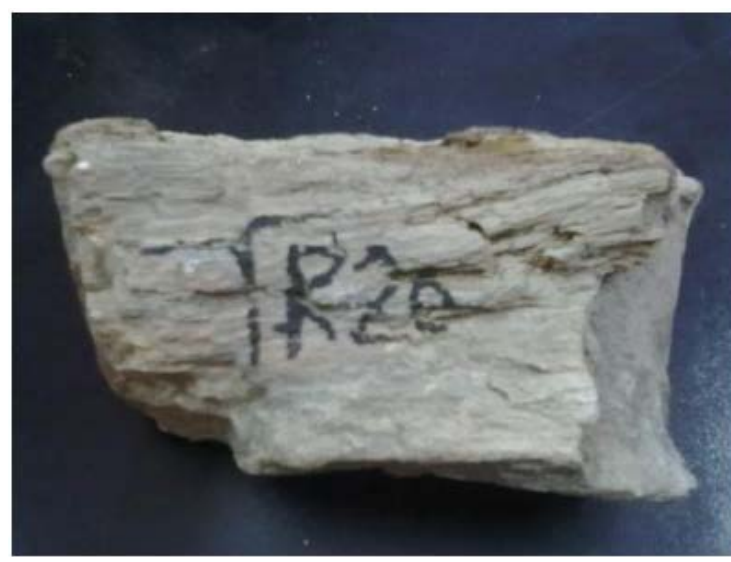

(a)

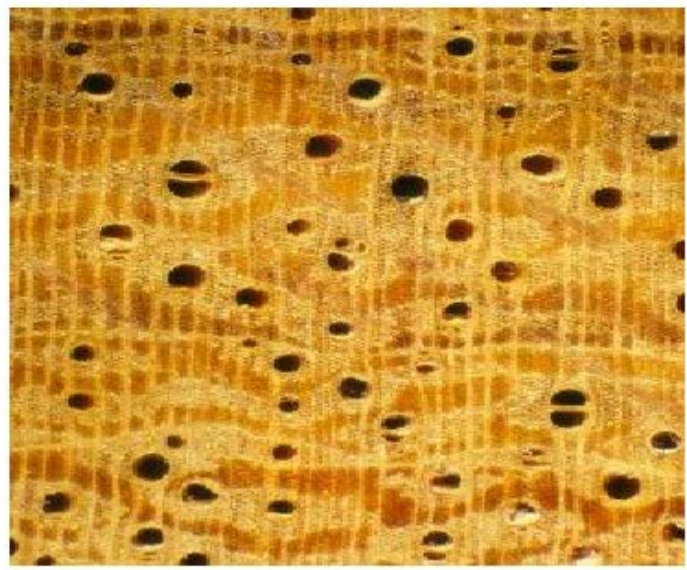

(c)

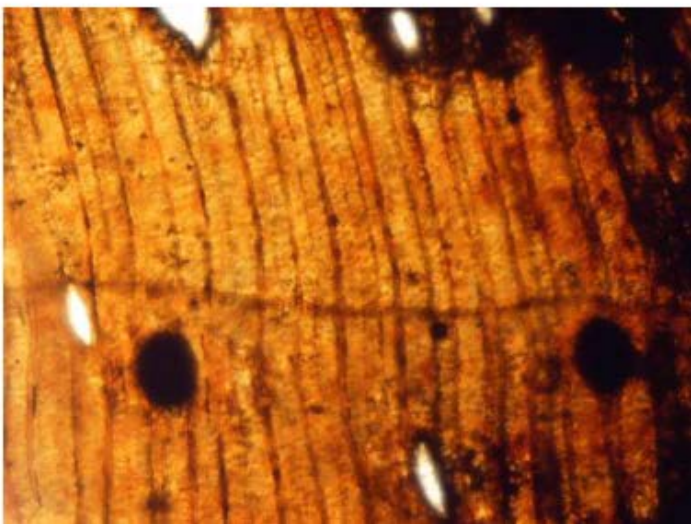

(b)

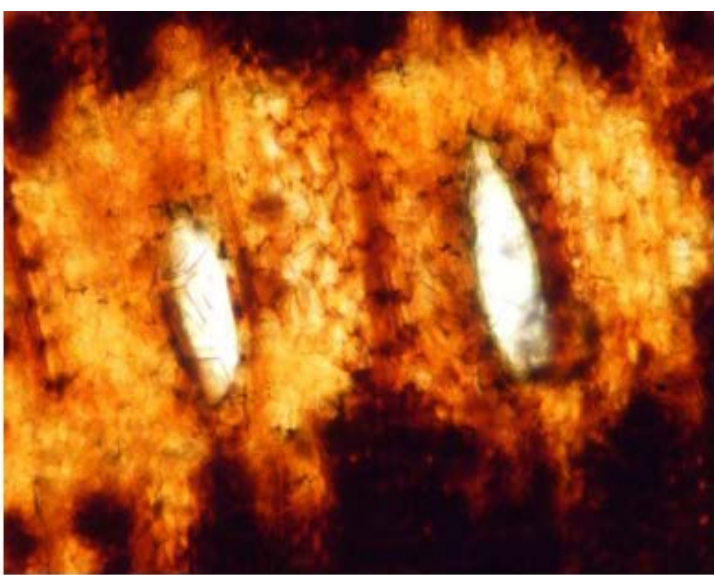

(d)

Plate 1. Ougenioxylon chinjiensis sp. nov. (a) Tangenial longitudinal section showing distribution of xylem rays and end wall of vessels, $\times 100$; (b) Tangenial longitudinal section showing arrangement of xylem rays, $\times 40$; (c) Radial longitudinal section showing the nature of xylem rays, $\times 160$; (d) Radial longitudinal section showing the pits on the wall of vessels, $\times 600$. 


\section{Diagnosis}

\subsection{Ougenioxylon chinjiensis}

Wood diffuse porous. Growth rings distinct. Vessel small to medium sized, mostly solitary as well as in radial multiples of 2 cells, t.d. 40 - $130 \mu \mathrm{m}, 3$ - 7 per sq. mm, r.d. 60 - $297 \mu \mathrm{m}$ vessel members storied, short with truncated or tailed ends perforation simple intervessel pit pairs small perforation simple; intervassel pit small to medium sized, simple, alternate, circular and crowded. Tylosis absent. Parenchyma paratracheal and apotracheal parenchyma paratracheal parenchyma copious, vasicentric to aliform few aliform-confluent, apotracheal parenchyma diffuse as scattered cells and terminal, xylem rays 1 - 3 mostly Biseriate, 12 - 18 per mm, 10 - 25 cells high; ray tissue homogeneous ray homocellular cells, consisting of procumbent cells. Fibres mostly libriform small, polygonal, septate, thick walled, 5 - $10 \mu \mathrm{m}$ in diameter.

\subsection{Holotype}

Thati Rest House, Chinji National Park, district Khushab, Punjab, Pakistan.

Basir Ahmed Arain, TR20, 1993 (Paleobotany museum, Institute of Plant Science, University of Sindh, Jamshoro, Sindh, Pakistan).

Horizon: Chinji Formation.

Age: Late Miocene.

\subsection{Morphological Description}

Fossil wood consist of a single piece of silicified wood which is ca. $22 \mathrm{~cm}$ long and $8 \mathrm{~cm}$ broad. The colour of fossilized wood is dark brown (Plate 1(a)).

\subsection{Anatomical Description}

\subsubsection{Cross Section}

Plates 1(b)-(d)

Wood diffuse porous. Growth rings distinct, delimited by 1 - 2 cells thick lines of terminal parenchyma. Vessels small to medium sized, oval in shape, unevenly distributed in ground mass, solitary as well as in radial multiples of 2, 3 - 7 per sq. mm. Radial diameter ranges from $60-297 \mu \mathrm{m}$ tangential diameter ranges from 40 - 130 $\mu \mathrm{m}$ tyloses absent wood parenchyma paratracheal and apotracheal, paratracheal abundant, mostly vesicentric to aliform occasionally aliform to confluent. Appotracheal diffuse as solitary or arranged in uniseriate thick lines, delimating growth rings. The shape of parenchyma cells round to oval, diameter ranges from $10-25 \mu \mathrm{m}$. Fiber cells are polygonal in shape, thick walled, diameter ranges from 5 - $13 \mu \mathrm{m}$. Xylem rays are mostly thin running on either side of the vessels

\subsubsection{Tangential Longitudinal Section \\ Plate 2(a), Plate 2(b)}

Vessels composed of elongated cells, their length ranges from 140 - $260 \mu \mathrm{m}$ with truncate to tailed ends. Vessels are irregularly distributed. Solitary vessels oval in shape those in radial multiples flattened at the places of contact. Xylem rays are numerous, mostly biseriate, homogenous consisting of procumbent cells, 10 - 25 cells high, diameter ranges from 15 - $30 \mu \mathrm{m} 10-18$ rays per mm. Intervessel pits are simple, alternate, circular to oval and some are elliptical in shape and crowded.

\subsubsection{Radial Longitudinal Section}

Plate 3(a), Plate 3(b)

Vessels segments elongated, length of vessels member ranges from 140 - $260 \mu \mathrm{m}$, and breadth ranges from 110 - $360 \mu \mathrm{m}$. End wall transverse, perforation simple, pits cells rounded alternate. The wood fibers are septate.

\subsection{Comparison with Modern Wood}

There is a close resemblance in almost all anatomical attributes of the discussed fossil wood with the wood structure of modern genus Ougenia Benth, belonging to the family Leguminosae. After the examination of 


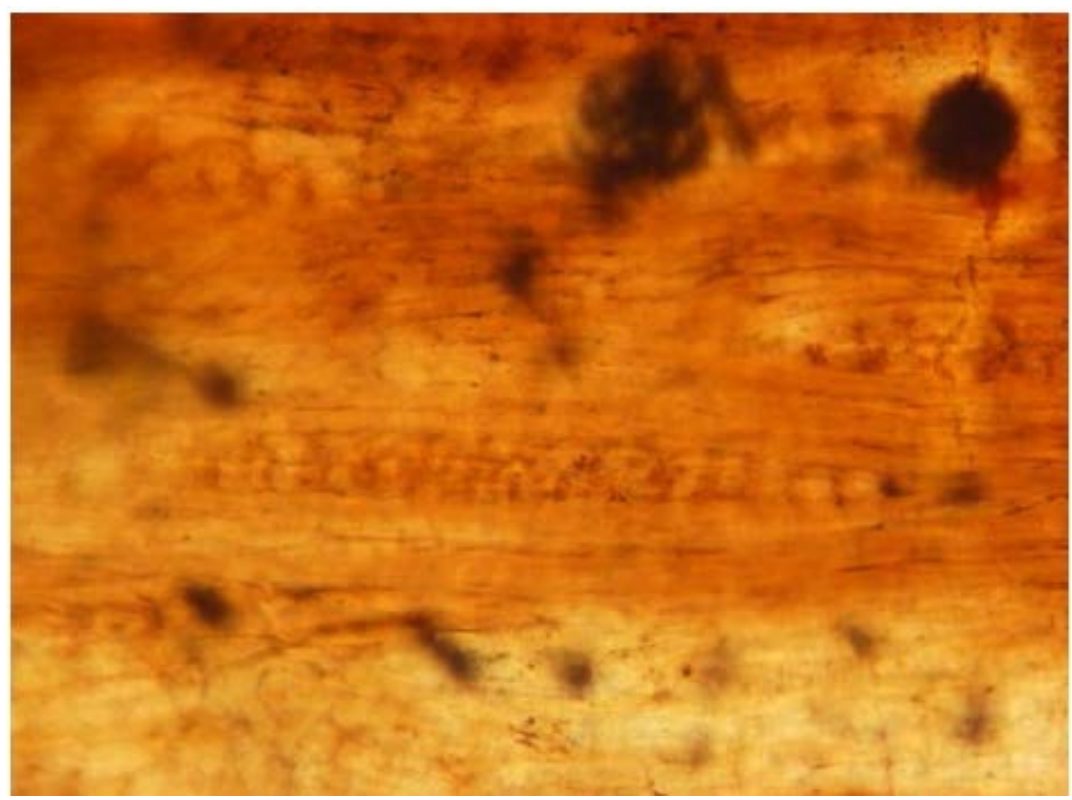

(a)

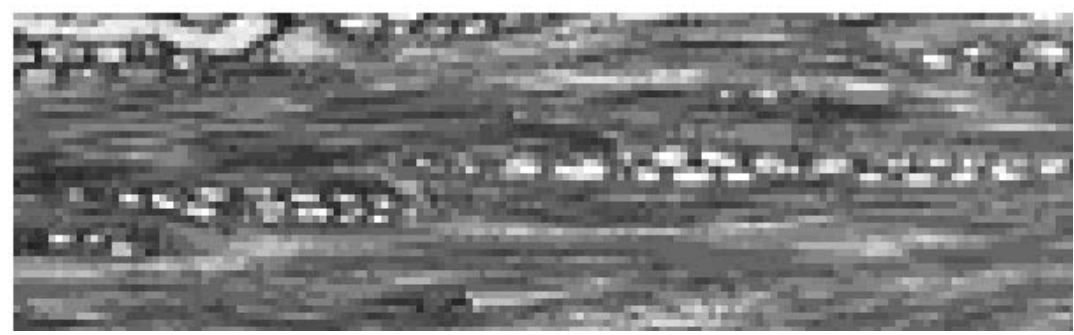

(b)

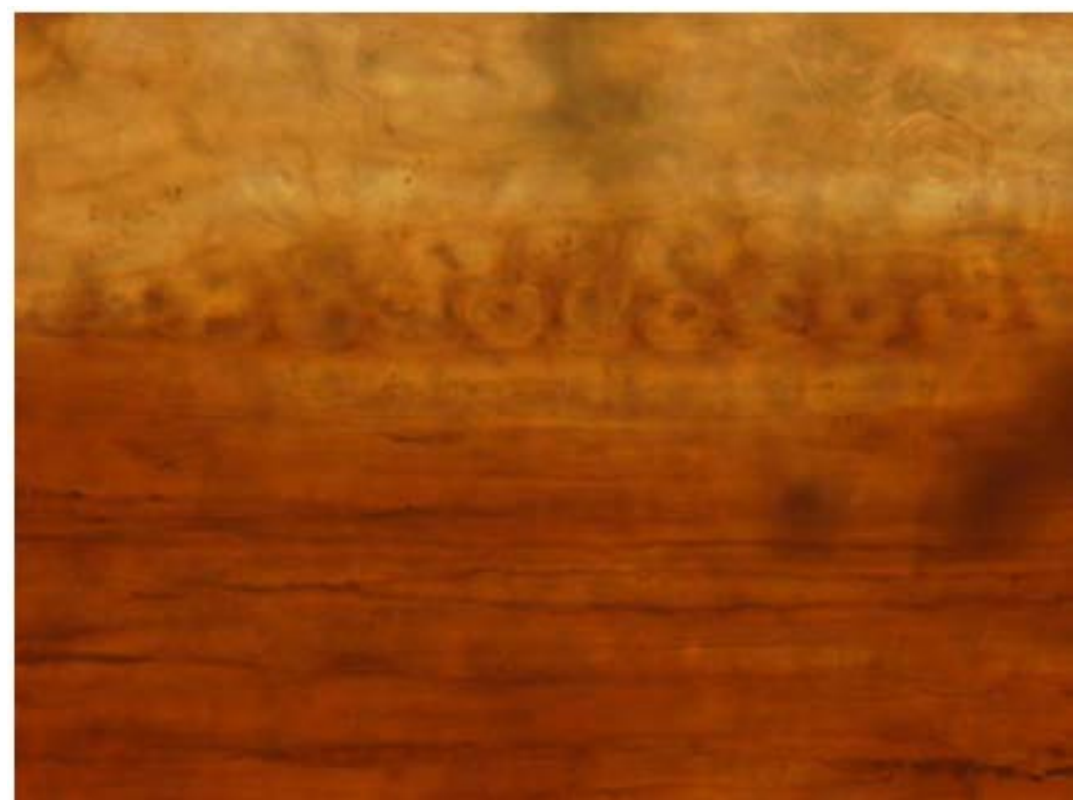

(c)

Plate 2. Ougenioxylon chinjiensis sp. nov. (a) Tangenial longitudinal section showing distribution of xylem rays and end wall of vessels, $\times 100$; (b) Tangenial longitudinal section showing arrangement of xylem rays, $\times 40$. 


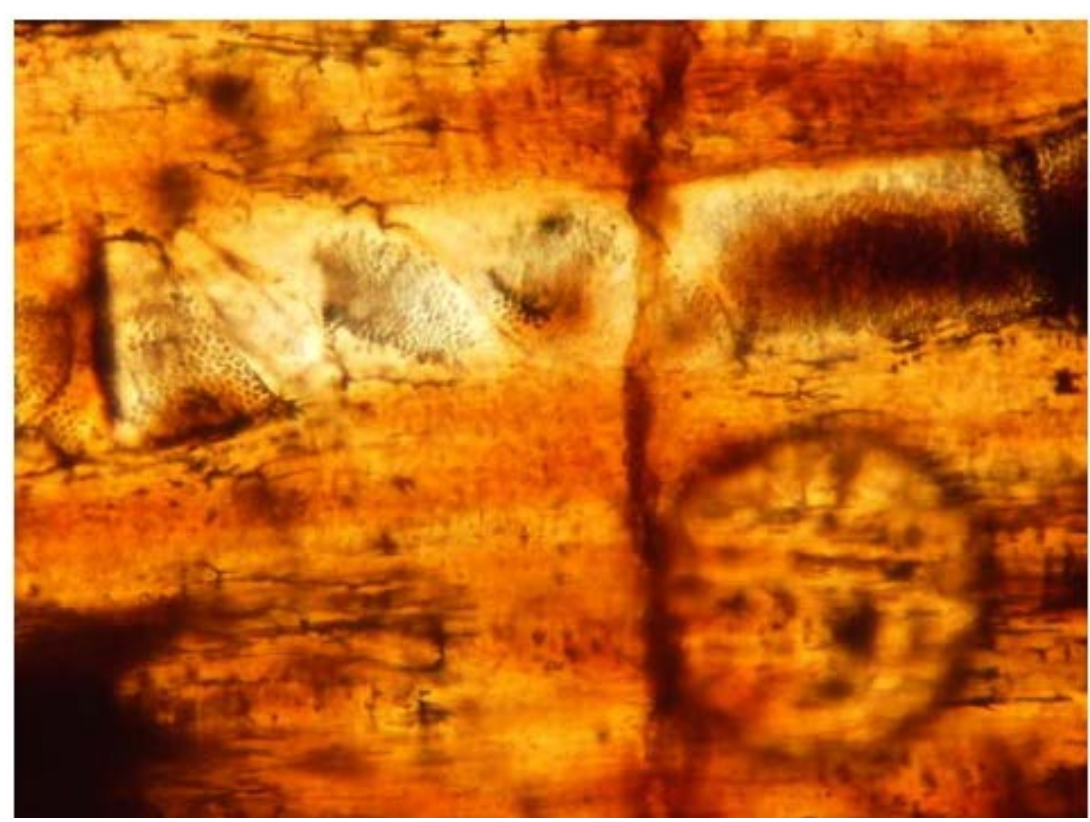

(a)

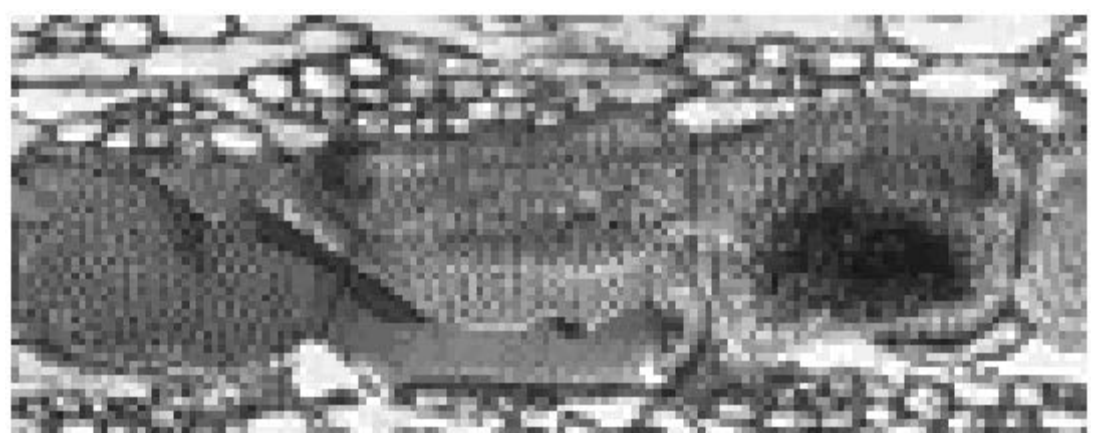

(b)

Plate 3. Ougenioxylon chinjiensis sp. nov. (a) Radial longitudinal section showing the nature of xylem rays and pits on the wall of vessels, $\times 100$; (b) Radial longitudinal section showing the pits on the wall of vessels of the living Ougenia (Inside wood).

anatomical structure on published description and phtorographs of the modern wood of Ougenia Benth, indicates closest resemblance with wood anatomical structure of Ougenia dalbergioides Benth [20] [21].

In both, the fossil wood and the modern wood Ougenia dalbergioides the growth rings are marked by terminal parenchyma, the vessels are small to large mostly solitary, often short redial of $2-4$. The parenchyma mostly vasicentric to aliform occasionally aliform to confluent. The xylem rays are storied, 1 - 4 (mostly $2-3$ ) seriate and composed of procumbent cells only and the fibers are semi libriform to libriform and septate.

Due to close resemblance of the fossil wood with the wood structure of the modern genus Ougenia Benth. It has been assigned to the genus Ougenioxylon.

The genus Ougenia Benth comprises of with 2 species, distributed in India and Pakistan, represented locally by only 1 species.

\subsection{Comparision with Fossil Woods}

Hitherto only one species of Ougenia dalbergioides is reported from Tertiary deposits of Assam. The detailed comparison of this reported species with fossil wood under investigation is given in Table 1.

As the fossil wood described in the contribution shows differences from other described species of Ougenioxylon, therefore it is considered as new species and it is named Ougenioxylon chinjieinsis sp. nov. (Table 2). 
Table 1. Comparison of fossils related to Ougenioxylon.

\begin{tabular}{|c|c|c|c|c|c|}
\hline Species & Wood & Vessels & Parenchyma & Xylem & Fibres \\
\hline $\begin{array}{l}\text { Ougenioxylon } \\
\text { tertiarum } \\
\text { Parakash \& } \\
\text { Tripathi } \\
\text { (1975) }[22]\end{array}$ & $\begin{array}{l}\text { Diffuse } \\
\text { porous }\end{array}$ & $\begin{array}{l}\text { Small to large t.d. } 40 \text { - } 260 \mu \mathrm{m} \\
3 \text { - } 7 \text { vessels/sq. mm mostly } \\
\text { solitary as well as in redial } \\
\text { multiple of } 2 \text { - } 4 \text { inter vessel } \\
\text { pit-pairs small, vestured, } \\
\text { border oval to elliptical with } \\
\text { lenticular orifices. }\end{array}$ & $\begin{array}{l}\text { Paratracheal and apotracheal; } \\
\text { Vascicentric, aliform to confluent; } \\
\text { apotracheal parenchyma diffuse } \\
\text { as scattered cells and terminal; } \\
\text { parenchyma strands storied } \\
\text { and crytalliferous. }\end{array}$ & $\begin{array}{l}\text { Rays } 1 \text { - } 4 \text { (mostly } 2 \text { - 3) } \\
\text { seriate procumbent } 3 \text { - } 20 \\
\text { ccells high, } 8 \text { - } 10 \\
\text { rays/mm homogeneous, } \\
\text { and homocellular. }\end{array}$ & Septate \\
\hline $\begin{array}{l}\text { Ougenioxylon } \\
\text { chinjiensis } \\
\text { sp. nov. }\end{array}$ & $\begin{array}{l}\text { Diffuse } \\
\text { porous }\end{array}$ & $\begin{array}{l}\text { Small to medium, } 40 \text { - } 130 \\
\mu m \text { in diameter, } 3 \text { - } 7 \text { vessels/ } \\
\text { sq. mm, mostly solitary as well } \\
\text { as in radial multiples of } 2 \text {, } \\
\text { inter vessel pits are alternate } \\
\text { circular, oval to elliptical. }\end{array}$ & $\begin{array}{l}\text { Paratracheal and apotracheal; } \\
\text { Mostly vascicentric, aliform } \\
\text { to confluent; apotracheal } \\
\text { parenchyma form thick } \\
\text { lines of terminal parenchyma; } \\
\text { parenchyma strands storied. }\end{array}$ & $\begin{array}{l}\text { Mostly biseriate, occasionally } \\
3 \text { seriate } 10 \text { - } 20 \text { cells high, } \\
10 \text { - } 19 \text { rays/mm homogenous, } \\
\text { homocellular procumbent. }\end{array}$ & Septate \\
\hline
\end{tabular}

Table 2. Graphical and stratigraphical break-up of fossils related to the genus Ougenia Benth.

\begin{tabular}{ccc}
\hline Species & Reported by and Year & Locality \\
\hline Ougenioxylon tertiarum & Prakah \& Tripathi, 1975 [22] & Assam, India \\
Ougenioxylon chinjiensis sp. nov. & Soomro et al. & Punjab, Pakistan \\
\hline
\end{tabular}

The specific epithet refers to Chinji Formation to which fossil wood belongs.

\section{Conclusion}

The anatomical character of the fossil wood indicates that it has diffuse porous wood and the growth rings are absent or indicated by terminal parenchyma. These characters indicate the existence of tropical type of climate of that time.

\section{References}

[1] Blanford, W.T. (1879) On the Geology of Sind. Ind. Geol. Survey.

[2] Khan, K.M. and Rehmatullah, Ch. (1968) Sapindoxylon petaroensis sp. nov. A New Species of Dicot Wood from the Late Tertiary Deposits of Sindh. Sindh University Research Journal (Science Series), 3, 137-142.

[3] Khan, K.M. and Rehmatullah, Ch. (1971) Albizzioxylon dhaproense sp. nov. A New Species of Silicified Fossil Wood from Ranikot Formation (Paleocene) near Amri, Sindh. Sindh University Research Journal (Science Series), 5, 207-213.

[4] Khan, K.M., Ahemd, M.R. and Rehmatullah, Ch. (1972) Palmoxylon amriense sp. nov. A New Species of Palm from Ranikot Formation (Paleocene) near Amri Sindh. Palaeontographica Abteilung B, 132, 128-129.

[5] Khan, K.M. and Rajput, M.T.M. (1976) Laurinoxylon rehmanense sp. nov. A New Species of Fossil Dicot. Wood from Tertiary Rocks of Sindh, Pakistan. Sindh University Research Journal (Science Series), 9, 5-13.

[6] Rehmatullah, Ch., Nizamani, Z.A. and Khan, K.M. (1984) Palmoxylon surangei Lakhanpal (1955). A Petrified Wood from Dhapro Stone Beds (Lower Paleocene) of Rehman Dhoro, District Dadu, Sindh, Pakistan. Pakistan Journal of Botany, 16, 61-64.

[7] Rajput, M.T.M. and Khan K.M. (1982) Two New Species of Fossil Woods from Ranikot Fort Area of Sindh. Pakistan Journal of Botany, 14, 75-87.

[8] Rajput, M.T.M. and Khan, K.M. (1984) Araucarioxylon sp. A Silicified Gymnosperm Wood from Manchhar Formation. Pakistan Journal of Botany, 16, 53-60.

[9] Saeed, M., Nizamani, Z.A. and Bhatti, N.M. (1984) Anatomical Studies of a Stem Fossil from Ranikot Fort Area, District Daud, Sindh, Pakistan. Sindh University Research Journal (Science Series), 16, 35-40.

[10] Rajput, M.T.M., Syeda, S.T. and Khan, K.M. (1985) Myristicoxylon ranikotensis sp. nov. A Silicified Dicot Wood from Ranikot Fort Area, District Dadu, Sindh. Pakistan Journal of Botany, 17, 247-252.

[11] Ahmed, B., Rajput, T. and Khan, K.M. (1989) Laurinoxylon ellipticum sp. nov. A New Petrified Taxon of Laraceae from the Tertiary Deposits of Sind, Pakistan. Sindh University Research Journal (Science Series), 21, 29-36. 
[12] Ahmed, B., Khan, M.Z., Rajput, T. and Khan, K.M. (1991) Mangiferoxylon pakistanicum sp. nov. A New Fossil Species of the Family Anacardiaceae from Ranikot Fort Area. Pakistan Journal of Botany, 23, 62-69.

[13] Ahmed, B., Rajput, T. and Khan, K.M. (1991) Siderinium pitensis sp. nov. A New Species of Silicified Fossil Dicot Wood from Tertiary Deposits of Sindh, Pakistan. Pakistan Journal of Botany, 23, 236-242.

[14] Ahmed, B., Arain, C.R. and Khan, K.M. (1993) Two New Species of Terminalioxylon from Ranikot Fort Area, District Dadu, Sindh, Pakistan. Sindh University Research Journal (Science Series), 23, 27-41.

[15] Bhutto, I., Ahmed, B., Arain, C.R. and Khan, K.M. (1993) Lagarstromiaxylon ranikotensis sp. nov. A New Species of Lythraceae from the Tertiary Sequences of Sindh, Pakistan. Sindh University Research Journal (Science Series), 22, 25-32.

[16] Ahmed, B., Rajput, M.T.M. and Soomro, N. (2007) Anogeissoxylon rehmannens sp. nov. A New Fossil Species of Family Combretaceae from Rehman Dhoro Dist. Jamshoro, Sindh, Pakistan. Pakistan Journal of Botany, 39, 2337-2344.

[17] Ahmed, B., Rajput, M.T.M., Nabila, S.J. and Soomro, N. (2007) Euphorioxylon thanobolnsis sp. nov. A New Species of Fossil Wood Family Sapindaceae fo Thanobolakhan Dist. Jamshoro, Sindh, Pakistan. Pakistan Journal of Botany, 39, 2317-2325.

[18] Shar, M., Trimizi, S.A.S. and Ahmed, B. (2007) Shoreoxylon ranikotensis sp. nov. A New Species of Fossil Wood Dipterocarpiaceae from Ranikot Fort Area, District Jamshoro, Sindh, Pakistan. Pakistan Journal of Botany, 39, 23272335.

[19] Weatherhead, A.V. (1938) The Preparation of Micro-Sections of Rocks. Watson Microscope Record 43, London, 3.

[20] Pearson, R.S. and Brown, H.P. (1932) Commercial Timbers of India 1. Government of India, Central Publication Branch, Calcuta. (Printed at the University Press Oxford)

[21] Metcalfe, C.R. and Chalk, L. (1950) Anatomy of the Dicotyledons. Vol. I \& 2, Oxford Press, Oxford.

[22] Prakash, U. and Tripathi, P.P. (1975) Fossil Dicotyledonous Woods from the Tertiary of Eastern India. Palaeobotanist, 24, 271-280. 
Scientific Research Publishing (SCIRP) is one of the largest Open Access journal publishers. It is currently publishing more than 200 open access, online, peer-reviewed journals covering a wide range of academic disciplines. SCIRP serves the worldwide academic communities and contributes to the progress and application of science with its publication.

Other selected journals from SCIRP are listed as below. Submit your manuscript to us via either submit@scirp.org or Online Submission Portal.
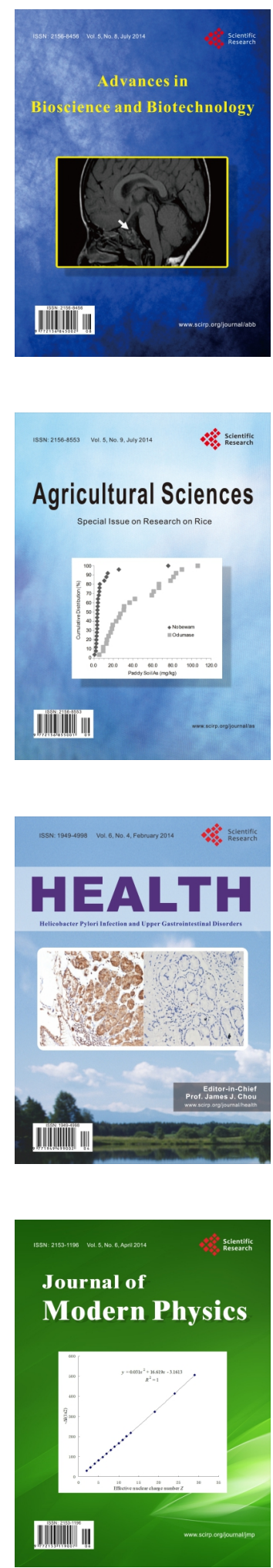
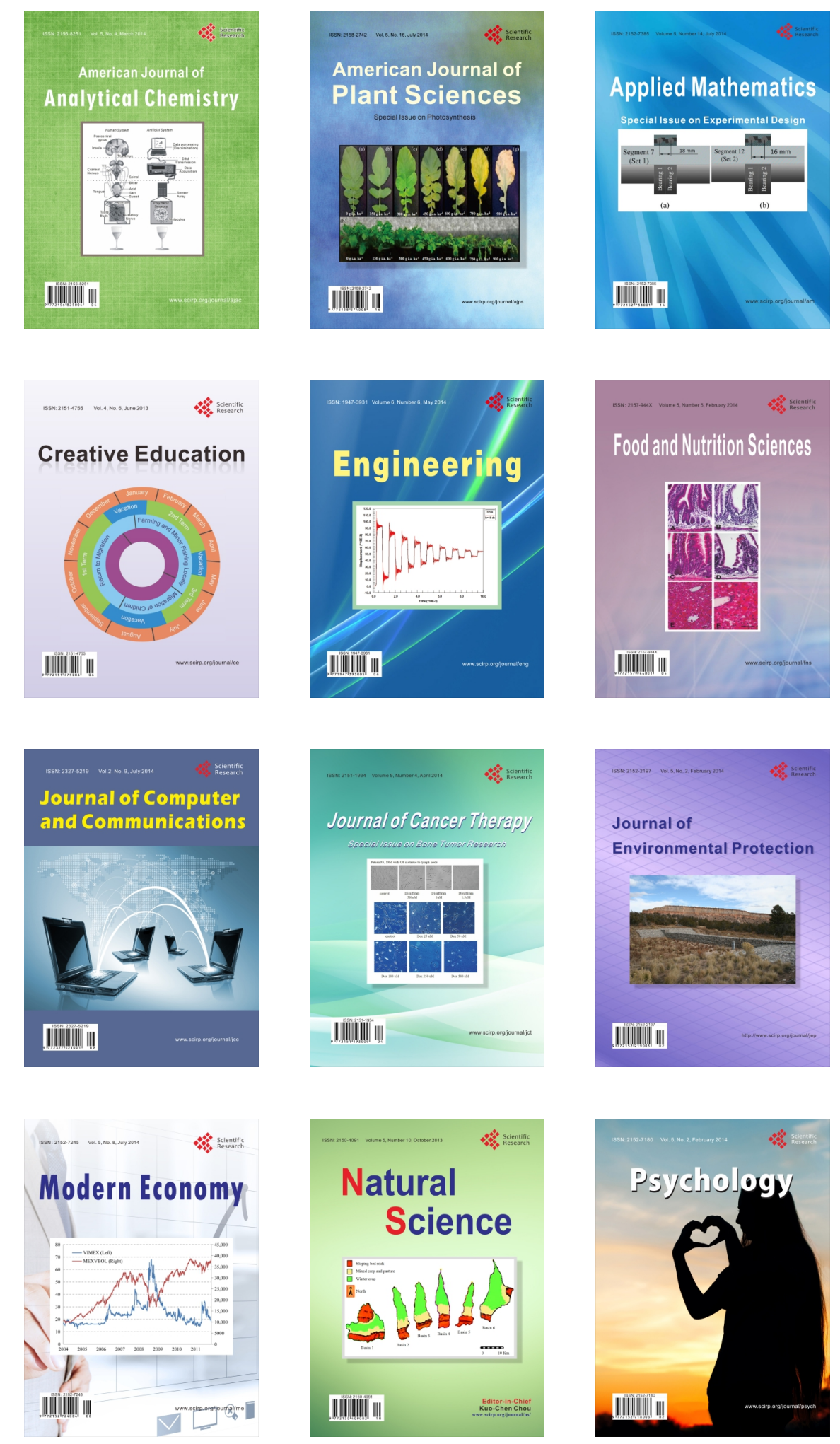